\title{
Perceived health and academic performance among adolescents from public schools in the city of Córdoba
}

\author{
Romina Vitale, MSc ${ }^{a}$, Emilse Degoy, B.S. ${ }^{b}$ and Prof. Silvina Berra, M.D. ${ }^{b}$
}

\begin{abstract}
Introduction. During adolescence, school performance may be related to health, and academic achievements at this age can have an impact on the future. Our objective was to assess the relationship between academic performance and perceived health among adolescents, considering sociodemographic characteristics
\end{abstract} of their families.

Population and Methods. Cross-sectional pilot study conducted in a sample of adolescents attending common basic courses of three public secondary schools in the city of Córdoba (Argentina). Academic performance was calculated as the average grade in all subjects; performance was considered satisfactory if equal to or higher than 6. Perceived health was assessed using the KIDSCREEN-52 questionnaire, which scores ten dimensions. In addition, age, sex, maternal education level, socioeconomic level and household composition were also recorded. Univariate and bivariate analyses and multivariate logistic regression models were conducted.

Results. Five hundred fifty-four adolescents participated, $52 \%$ of them were girls. Unsatisfactory academic performance (27.6\%) was more common among adolescents who evidenced a worse relationship with parents (OR: 2.68, 95\% CI: 1.22-5.85) and a better relationship with peers (OR: 0.46, 95\% CI: $0.26-0.82)$. Stratification by socioeconomic level showed differences: among those with a high socioeconomic level, an unsatisfactory performance was more common among adolescents who perceived themselves as having a low autonomy, while it was more common among those who perceived a worse school environment in the middle-low socioeconomic level.

Conclusion. Academic performance was associated with psychosocial dimensions of health, such as relationship with family members, peers, autonomy and school environment. Key words: adolescents, education, quality of life, child's health.

http:/ /dx.doi.org/10.5546/aap.2015.eng.526

Funding:

Parcially funded by a

SECYT-UNC grant. Resol.

$214 / 2010$

Conflict of Interest:

None.

Received: 12-30-14

Accepted: 06-10-15 result of a previous status and conditions subsequent stages due to sensitivity and increased dynamics in comparison to other stages of life. ${ }^{1}$

Health is a resource that includes personal, social, physical and psychological abilities, allowing people to face their environment and meet their aspirations and needs. ${ }^{2}$ During childhood and adolescence, the concept of health also includes the ability to carry out activities adequate for their age, cognitive development, emotions, self-perception, interpersonal relationships and with the environment, and develop daily activities. $^{3}$

Learning and academic performance are essential during childhood. Academic achievements in this stage will have an impact on social and working participation of the future adult individuals. ${ }^{4,5}$ An important indicator of the teachinglearning process is the academic performance, ${ }^{6}$ defined as "students' output at educational facilities, usually expressed by means of grades;"7 at the same time, it is known to be influenced by family, socioeconomic, cultural and political factors. ${ }^{8}$

At present, it is possible to study adolescents' health by means of multidimensional theoretical models and considering their own perspectives, ${ }^{9,10}$ and to analyze the relation between health and school performance in our setting. The bibliography includes few investigations that establish a relation between school performance and health indicators, such as wellbeing, satisfaction with life, ${ }^{11}$ and emotional health. ${ }^{12} \mathrm{~A}$ study conducted in Chile indicated that students who failed at school had stated that they 
were not comfortable with their schools and considered themselves worse than average. ${ }^{13}$ Such precedent has led to the hypothesis that academic performance may be associated with the psychosocial dimensions of health-related quality of life (HRQoL).

The objective of this investigation was to analyze the association between the annual average academic performance (AP) and perceived health among adolescents attending public schools in the city of Córdoba, taking into account their families' socioeconomic characteristics.

\section{POPULATION AND METHODS}

A cross-sectional pilot study was conducted in male and female adolescents attending common basic courses (first through third year) at three public secondary schools in the city of Córdoba, whose directors authorized the conduction of the study. The total number of students enrolled in the common basic course was 862 . The sample size was estimated at 393 students necessary for a two-tailed test, accepting an alpha risk of 0.05 and a beta risk of 0.2 to detect a 3-point or higher difference in HRQoL score. The screening procedure included a form that explained the objectives of the study and overall characteristics of the instrument, and requested legal guardians to sign the consent. The survey was administered in the classroom in two different school days so that adolescents who were absent on the first day had a second chance to participate in the study. An informed consent signed by legal guardians and students' assent were requirements for participation; no other exclusion criteria were in place.

$\mathrm{AP}$ was determined based on average grades for the school year considering academic records. Mean grade was considered unsatisfactory if lower than 6 , and satisfactory if equal to or higher than 6 .

Adolescents completed a questionnaire that included questions on their age, sex, perceived health, maternal education level, household material resources, and family structure. In order to assess perceived health, the tool used was the KIDSCREEN-52 for HRQoL, which measures 10 dimensions: physical well-being, psychological well-being, moods and emotions, self-perception, autonomy, parent relations and home life, social support and peers, school environment, social acceptance, and financial resources..$^{14}$ KIDSCREEN is a generic instrument developed using qualitative techniques that provided items based on children's and adolescents' discourse ${ }_{1}^{15}$ selecting its content and verifying its reliability and validity through modern statistical techniques. ${ }^{16}$ This instrument was transculturally adapted to the 8 to 18 -year-old Argentine population, ${ }^{17}$ and its metric properties were also verified for the local context. ${ }^{20}$ The KIDSCREEN questions are answered using a Likert scale with frequency and intensity options and assigning each answer a score of 1 to 5 . Therefore, the average score obtained in each dimension is estimated first; then the score is transformed into a continuous linear set using a RASCH model, and standardized to a mean of 50 points and a standard deviation (SD) of 10 points. Finally, each dimension is categorized into three levels, with a cut-off point at $\pm 1 / 2 \mathrm{SD}$; levels are low: $<45$ points, middle: $45-55$ points, or high: $>55$ points. ${ }^{14}$

School age as a variable was estimated to indicate whether adolescents' age corresponded to the expected age for their school year or if they were older.

Maternal education level was classified into no education or up to primary education, secondary education, or tertiary or university education. Socioeconomic level (SEL) was established based on the Family Affluence Scale (FAS), ${ }^{19}$ which is made up of questions on household material resources (number of cars and computers owned by the family, whether the adolescent has his/ her own room, and family vacations in the past 12 months). Based on this score, SEL was categorized into low, middle or high. Family structure was considered nuclear when the family was made up of a mother and a father living together with their dependent children; singleparent when the family was made up of one or more children dependent on only one parent; extended single-parent when the family was made up of, at least, three vertical generations living together with only one parent responsible for children; blended when the family was established following the separation of one of the parents; or no father and no mother, when the family was made up of one or several children with no parents responsible for them.

The survey was self-administered by students, in their classroom at school. A member of the team explained the objectives of the study, its ethical considerations and how to complete the survey in advance. 


\section{Statistical analysis}

First of all, a univariate descriptive analysis of sample characteristics was done, estimating mean and SD for quantitative variables, and frequency distribution for categorical variables. Associations between categorical variables were explored using a $\chi^{2}$ test, while Student's $t$ test was used for those between quantitative variables; in both cases, the statistical significance level was established at $p<0.05$. Finally, multivariate logistic regression models were adjusted to analyze independent effect of variables.

As far as academic performance, a multiple logistic regression was used, estimated by means of OR and $95 \%$ confidence intervals (95\% CIs). The multivariate model included those variables that obtained a $p \leq 0.20$ in the bivariate analysis.

\section{Ethical aspects}

International ethics recommendations and good research practice in human health standards were adhered to during the investigation. The study was assessed and approved by the Institutional Ethics and Health Research Committee (CIES) of Sanatorio del Salvador.

\section{RESULTS}

Participation accounted for $64 \%$; 552 adolescents completed the questionnaire out of the 862 adolescents who made up the eligible population from the three schools. The main reason for not participating was lack of consent signed by the parents (233 cases), followed by absenteeism (43), lack of consent from parents (23) or lack of assent from adolescents (11). Annual average academic performance was not retrieved in 27 cases because they had dropped out of school or had been transferred to another school during the school year.

Fifty-two percent of participants were girls; $40.9 \%$ were one or more years older than the expected age for the school year. The mothers of $21.8 \%$ of participants had primary education or no education; $37.9 \%$ of adolescents lived within a type of family structure other than nuclear (Table 1).

AP was 6.61 points (SD 1.1). A grade of 6 or more was obtained by $72.4 \%$ of adolescents, who became the satisfactory AP group. In the bivariate analysis, an unsatisfactory AP was associated with male sex $(p=0.01)$, an older-thanexpected age $(p=0.01)$ and it was more common among adolescents with no father and no mother $(p=0.04)$ (Figure 1), but an association with SEL and maternal education was not demonstrated.

HRQoL dimensions associated with AP in the bivariate analysis were moods, parent relations and school environment, which obtained the

TABLE 1. Sample characteristics by sex

\begin{tabular}{lccc}
\hline & Girls & Boys & Total \\
\hline Sex, \% (n) & $265(52 \%)$ & $287(48 \%)$ & 552 \\
Age (SD) & $14.1(1.3)$ & $13.8(1.3)$ & $13.9(1.3)$ \\
School age, \% (n) & & $59.1 \%(321)$ \\
Theoretical age & $59.5 \%(153)$ & $58.7 \%(168)$ & $23.6 \%(128)$ \\
1 year older than expected & $22.2 \%(57)$ & $24.8 \%(71)$ & $17.3 \%(94)$ \\
2 or more years older than expected & $18.3 \%(47)$ & $16.4 \%(47)$ & $29.7 \%(146)$ \\
Maternal education, \% (n) & & & $48.5 \%(238)$ \\
Tertiary or university education & $28.0 \%(67)$ & $31.3 \%(79)$ & $21.8 \%(107)$ \\
Secondary education & $46.4 \%(111)$ & $50.4 \%(127)$ & \\
Complete primary education or less & $25.5 \%(61)$ & $18.3 \%(46)$ & $23 \%(123)$ \\
Socioeconomic level (FAS), \% (n) & & & $45.7 \%(244)$ \\
Low & $27 \%(70)$ & $19.2 \%(53)$ & $31.3 \%(167)$ \\
Middle & $43.4 \%(112)$ & $47.8 \%(132)$ & \\
High & $29.5 \%(76)$ & $33 \%(91)$ & $62.1 \%(342)$ \\
Family structure, $\%$ (n) & & & $19.2 \%(106)$ \\
Nuclear & $57.0 \%(151)$ & $3.8 \%(21)$ \\
Single-parent & $25.3 \%(67)$ & $66.8 \%(191)$ & $11.8 \%(65)$ \\
Extended single-parent & $2.6 \%(7)$ & $13.6 \%(39)$ & $3.1 \%(17)$ \\
Blended & $12.1 \%(32)$ & $4.9 \%(14)$ & $11.5 \%(33)$ \\
No father and no mother & $3 \%(8)$ & $3.1 \%(9)$ & \\
\hline
\end{tabular}

FAS: Faily affluence scale. 
lowest average scores among adolescents with an AP lower than 6 (unsatisfactory) when compared to those with a satisfactory AP (Table 2). The percentage of adolescents with a poor score in the "school environment" dimension (score $<45$ in the KIDSCREEN questionnaire) was higher among those with an unsatisfactory AP (61.2\%) than among those with an average grade above 6 $(40.1 \%)$.

In the multivariate analysis, an unsatisfactory $\mathrm{AP}$ was confirmed to be more common among male adolescents (adjusted OR [aR]: 1.75, 95\% CI: 1.12-2.73) when compared to female adolescents, among those who were one year (aR: $3.12,95 \%$ CI: $1.70-5.71$ ) or two or more years older than expected ( ${ }_{\mathrm{a}}$ OR: $2.71,95 \%$ CI: 1.35-5.42) when compared to those with the theoretical age for the course they attended, among adolescents with a worse perception in terms of parent relations ( $\mathrm{aR}: 2.68,95 \% \mathrm{CI}: 1.22-5.5$ ) and the intermediate category of the peer and social support dimension ( OR: 0.46, 95\% CI: 0.26-0.82) when compared to those with a high score in these dimensions (Table 3).

When the sample was stratified by SEL, the difference in AP by school age was verified only among adolescents with a high SEL, and an unsatisfactory AP was more common among those who were one year (53.3\%, ${ }_{\mathrm{a}}$ OR: $7.52,95 \%$ CI: 2.01-28.13) and two or more years older than expected (66.7\%, ${ }_{\mathrm{a}}$ OR: 10.60, 95\% CI: 2.10-53.51) (Table 4).

A lower degree of autonomy was associated with a lower frequency of unsatisfactory AP among adolescents with a middle-low SEL (aR: 0.35 , 95\% CI: 0.15-0.80) and with a higher frequency among those with a high SEL ( $\mathrm{aR}$ : 3.89, 95\% CI: 1.03-14.63). Among adolescents with a middle-low SEL, an unsatisfactory AP was more common among those with a low perception in the "school environment" dimension ( OR: 3.13, 95\% CI: 1.11-8.82).

\section{DISCUSSION}

This study analyzes the relationship between health and school performance during adolescence and, to our knowledge, it is the first study on this topic in the field of pediatrics conducted in Argentina. Adolescence is a highly vulnerable stage of development; available evidence indicates a worsening of selfperceived health ${ }^{20,21}$ and academic performance ${ }^{11}$

FIGURE 1. Frequency of satisfactory or unsatisfactory annual average academic performance by sex, school age, and household composition

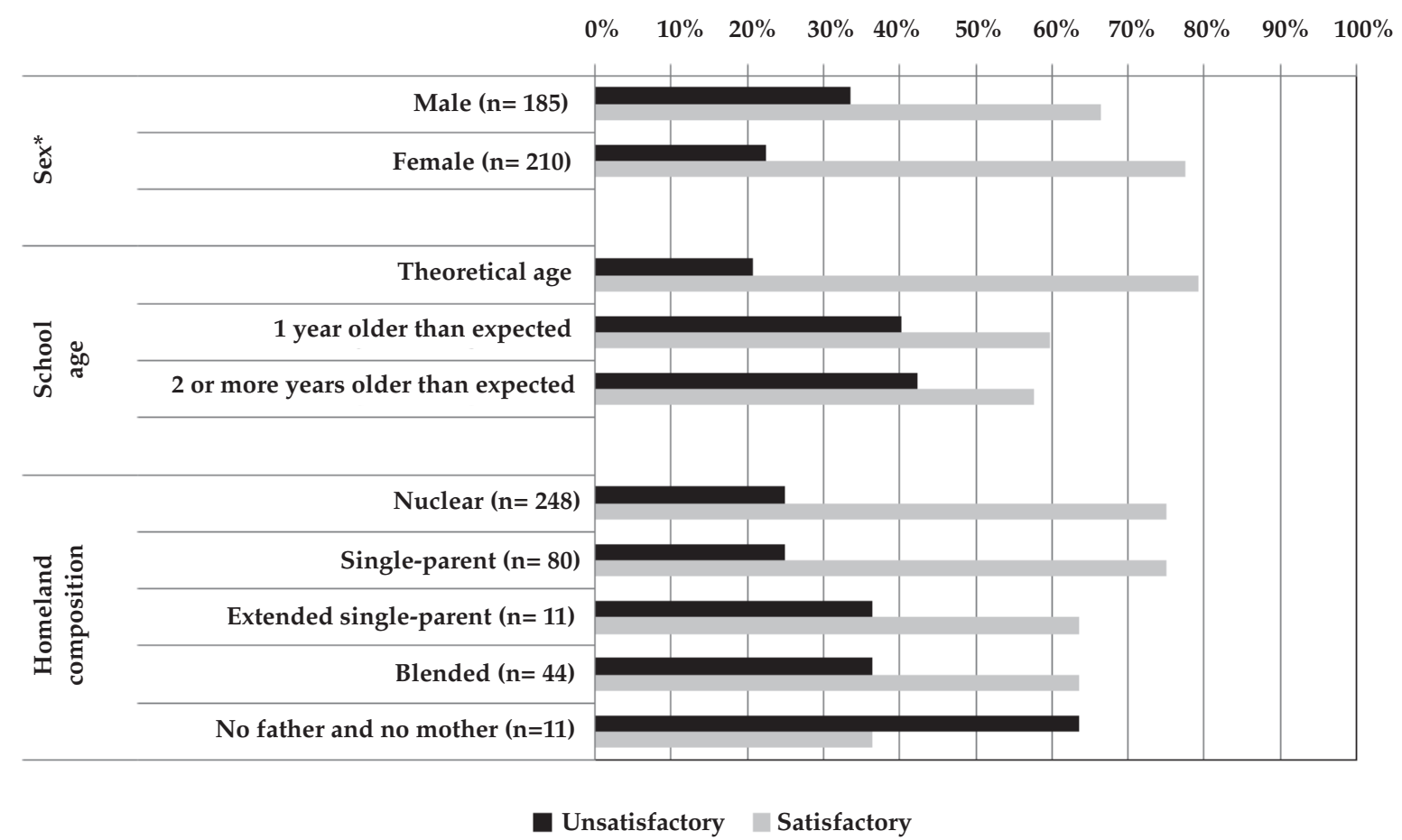

* Statistically significant differences $\left(\chi^{2} p<0.05\right)$ in the distribution of academic performance for each variable. 
during this period. Therefore, this is a critical time that should be considered by different disciplines, including pediatrics, given that health and academic achievements in this stage have a strong effect on health and a productive life as adults. ${ }^{5}$

Results show that a low AP was associated with a poor score in the following health dimensions: autonomy, peer relations, emotions in the family environment and perceptions regarding school environment. While prior investigations conducted in other countries are consistent with these results and demonstrated that, during childhood, besides classic indicators such as morbidity, physical well-being, stress, satisfaction with life, ${ }^{22-11}$ and emotional health ${ }^{12}$ were related to school performance; as per our findings, during adolescence, social dimensions of health seem to become more important. Another study conducted in the USA showed that different aspects of health, such as a sense of vitality, psychological well-being, connection with others, a low exposure to bullying and absence of stress have a positive effect on academic performance, and concluded that those with a better health have better academic outcomes. ${ }^{11}$
Adolescents face the challenge of spending either more time devoted to their academic goals or to their social goals, ${ }^{23}$ and during this stage there is a more prominent preference towards peers than towards school. ${ }^{24}$ In this study, adolescents who evidenced a stronger peer relation more commonly had a lower AP. As per SEL, autonomy among adolescents was associated with AP in a different sense, and showed a positive association among high SEL groups and a negative association among low SEL participants. The interpretation of these results is limited by the fact that the study population was a small sociocultural group that deserves a deeper analysis regarding the meaning of personal relations and academic achievements.

The relationship with parents is key in the teaching-learning process of students, and school environment may also favor a better academic performance. ${ }^{25}$ Adolescents who lived in an unconventional household had lower scores than those who lived with their father and mother, although this association was not verified in multivariate models, possibly due to the size of the sample. Some authors have stated that children who live in a nuclear family household

TABLE 2. Scores obtained in health-related quality of life dimensions among adolescent students in the city of Córdoba, 2010

\begin{tabular}{|c|c|c|c|c|c|c|c|c|c|}
\hline \multirow[b]{2}{*}{ HRQoL } & \multicolumn{4}{|c|}{ Unsatisfactory academic performance } & \multicolumn{4}{|c|}{ Satisfactory academic performance } & \multirow{2}{*}{$\begin{array}{c}\text { P value } \\
\chi^{2}\end{array}$} \\
\hline & $\begin{array}{l}\text { Mean } \\
(\mathrm{SD})\end{array}$ & $\begin{array}{c}\% \text { low } \\
\text { (n) }\end{array}$ & $\begin{array}{c}\% \text { middle } \\
\text { (n) }\end{array}$ & $\begin{array}{l}\% \text { high } \\
\text { (n) }\end{array}$ & $\begin{array}{c}\text { Mean } \\
\text { (SD) }\end{array}$ & $\begin{array}{c}\text { \% low } \\
\text { (n) }\end{array}$ & $\begin{array}{l}\% \text { middle } \\
\text { (n) }\end{array}$ & $\begin{array}{l}\% \text { high } \\
\text { (n) }\end{array}$ & \\
\hline $\begin{array}{l}\text { Physical } \\
\text { well-being }\end{array}$ & $\begin{array}{c}46.5 \\
(10.0)\end{array}$ & $\begin{array}{c}49.5 \% \\
(51)\end{array}$ & $\begin{array}{c}35.0 \% \\
(36)\end{array}$ & $\begin{array}{c}15.5 \% \\
(16)\end{array}$ & $\begin{array}{c}48.1 \\
(15.0)\end{array}$ & $\begin{array}{c}45.5 \% \\
(125)\end{array}$ & $\begin{array}{c}31.3 \% \\
(86)\end{array}$ & $\begin{array}{c}23.3 \% \\
(64)\end{array}$ & 0.237 \\
\hline $\begin{array}{l}\text { Psychological } \\
\text { well-being }\end{array}$ & $\begin{array}{c}51.6 \\
(10.1)\end{array}$ & $\begin{array}{c}24.5 \% \\
(26)\end{array}$ & $\begin{array}{c}46.2 \% \\
(49)\end{array}$ & $\begin{array}{c}29.2 \% \\
(31)\end{array}$ & $\begin{array}{l}51.6 \\
(9.2)\end{array}$ & $\begin{array}{c}23.0 \% \\
(65)\end{array}$ & $\begin{array}{c}46.6 \% \\
(132)\end{array}$ & $\begin{array}{c}30.4 \% \\
(86)\end{array}$ & 0.940 \\
\hline $\begin{array}{l}\text { Moods } \\
\text { and emotions }\end{array}$ & $\begin{array}{c}43.4 \\
(10.5)^{*}\end{array}$ & $\begin{array}{c}59.4 \% \\
(63)\end{array}$ & $\begin{array}{c}31.1 \% \\
(33)\end{array}$ & $\begin{array}{c}9.4 \% \\
(10)\end{array}$ & $\begin{array}{c}46.2 \\
(9.9)^{*}\end{array}$ & $\begin{array}{c}51.1 \% \\
(140)\end{array}$ & $\begin{array}{c}32.5 \% \\
(89)\end{array}$ & $\begin{array}{c}16.4 \% \\
(45)\end{array}$ & 0.146 \\
\hline Self-perception & $\begin{array}{c}50.9 \\
(10.5)\end{array}$ & $\begin{array}{c}28.8 \% \\
(30)\end{array}$ & $\begin{array}{c}40.4 \% \\
(42)\end{array}$ & $\begin{array}{c}30.8 \% \\
(32)\end{array}$ & $\begin{array}{l}50.1 \\
(9.1)\end{array}$ & $\begin{array}{c}31.3 \% \\
(87)\end{array}$ & $\begin{array}{c}42.1 \% \\
(117)\end{array}$ & $\begin{array}{c}26.6 \% \\
(74)\end{array}$ & 0.729 \\
\hline Autonomy & $\begin{array}{c}50.5 \\
(10.3)\end{array}$ & $\begin{array}{c}24.3 \% \\
(25)\end{array}$ & $\begin{array}{c}45.0 \% \\
(46)\end{array}$ & $\begin{array}{c}31.1 \% \\
(32)\end{array}$ & $\begin{array}{l}50.2 \\
(9.4)\end{array}$ & $\begin{array}{c}27.7 \% \\
(77)\end{array}$ & $\begin{array}{c}45.0 \% \\
(124)\end{array}$ & $\begin{array}{c}27.7 \% \\
(77)\end{array}$ & 0.729 \\
\hline $\begin{array}{l}\text { Parent relations } \\
\text { and home life }\end{array}$ & $\begin{array}{c}46.1 \\
(10.2)^{*}\end{array}$ & $\begin{array}{c}43.9 \% \\
(43)\end{array}$ & $\begin{array}{c}40.8 \% \\
(40)\end{array}$ & $\begin{array}{c}15.3 \% \\
(15)\end{array}$ & $\begin{array}{c}49.0 \\
(10.3)^{*}\end{array}$ & $\begin{array}{c}34.4 \% \\
(96)\end{array}$ & $\begin{array}{c}41.9 \% \\
(117)\end{array}$ & $\begin{array}{c}23.7 \% \\
(66)\end{array}$ & 0.114 \\
\hline $\begin{array}{l}\text { Peers and } \\
\text { social support }\end{array}$ & $\begin{array}{c}54.8 \\
(10.4)\end{array}$ & $\begin{array}{c}18.1 \% \\
(19)\end{array}$ & $\begin{array}{c}36.2 \% \\
(38)\end{array}$ & $\begin{array}{c}45.7 \% \\
(48)\end{array}$ & $\begin{array}{c}54.4 \\
(10.3)\end{array}$ & $\begin{array}{c}13.9 \% \\
(38)\end{array}$ & $\begin{array}{c}47.4 \% \\
(130)\end{array}$ & $\begin{array}{c}38.7 \% \\
(106)\end{array}$ & 0.154 \\
\hline $\begin{array}{l}\text { School } \\
\text { environment }\end{array}$ & $\begin{array}{l}43.5 \\
(8.4)^{*}\end{array}$ & $\begin{array}{l}61.2 \% \\
(63)^{* *}\end{array}$ & $\begin{array}{c}28.2 \% \\
(29)\end{array}$ & $\begin{array}{c}10.7 \% \\
(11)\end{array}$ & $\begin{array}{c}47.7 \\
(8.7)^{*}\end{array}$ & $\begin{array}{l}40.1 \% \\
(111)^{* *}\end{array}$ & $\begin{array}{c}44.0 \% \\
(122)\end{array}$ & $\begin{array}{c}15.9 \% \\
(33)\end{array}$ & 0.002 \\
\hline $\begin{array}{l}\text { Social } \\
\text { acceptance }\end{array}$ & $\begin{array}{c}44.6 \\
(11.6)\end{array}$ & $\begin{array}{c}57.9 \% \\
(62)\end{array}$ & $\begin{array}{c}10.3 \% \\
(11)\end{array}$ & $\begin{array}{c}31.8 \% \\
(34)\end{array}$ & $\begin{array}{c}45.1 \\
(10.3)\end{array}$ & $\begin{array}{c}53.4 \% \\
(150)\end{array}$ & $\begin{array}{c}18.9 \% \\
(53)\end{array}$ & $\begin{array}{c}27.8 \% \\
(78)\end{array}$ & 0.113 \\
\hline $\begin{array}{l}\text { Financial } \\
\text { resources }\end{array}$ & $\begin{array}{l}46.4 \\
(9.2)\end{array}$ & $\begin{array}{c}49.5 \% \\
(54)\end{array}$ & $\begin{array}{c}31.2 \% \\
(34)\end{array}$ & $\begin{array}{c}19.3 \% \\
(21)\end{array}$ & $\begin{array}{l}46.4 \\
(8.3)\end{array}$ & $\begin{array}{c}45.2 \% \\
(128)\end{array}$ & $\begin{array}{c}37.5 \% \\
(106)\end{array}$ & $\begin{array}{c}17.3 \% \\
(49)\end{array}$ & 0.538 \\
\hline
\end{tabular}

SD: standard deviation; HRQoL: health-related quality of life.

* Statistically significant differences (ANOVA $p<0.05$ ) in the mean scores obtained in HRQL dimensions by academic performance.

** Statistically significant differences $\left(\chi^{2} p<0.05\right)$ in the distribution of scores in HRQLL dimensionsby academic performance. 
TABLE 3. Variables related to unsatisfactory academic performance among adolescent students

\begin{tabular}{|c|c|c|c|}
\hline Variables & $\% *$ & ${ }_{c} \mathrm{OR}(95 \% \mathrm{CI})^{*}$ & ${ }_{\mathrm{a}} \mathrm{OR}(95 \% \mathrm{CI})^{* *}$ \\
\hline $\begin{array}{l}\text { Sex } \\
\text { Female } \\
\text { Male }\end{array}$ & 33.5 & $\begin{array}{c}22.4 \\
1.75(1.12-2.73)\end{array}$ & $\begin{array}{c}11 \\
2.28(1.35-3.83)\end{array}$ \\
\hline $\begin{array}{l}\text { School age* } \\
\text { Theoretical age } \\
1 \text { year older than expected } \\
2 \text { or more years older than expected }\end{array}$ & $\begin{array}{l}20.8 \\
40.3 \\
42.3\end{array}$ & $\begin{array}{c}1 \\
2.56(1.48-4.41) \\
2.78(1.49-5.21)\end{array}$ & $\begin{array}{c}1 \\
3.12(1.70-5.71) \\
2.71(1.35-5.42)\end{array}$ \\
\hline $\begin{array}{l}\text { Family structure* } \\
\text { Nuclear } \\
\text { Single-parent } \\
\text { Extended single-parent } \\
\text { Blended } \\
\text { No father and no mother }\end{array}$ & $\begin{array}{l}25.0 \\
25.0 \\
36.4 \\
36.4 \\
63.6\end{array}$ & $\begin{array}{c}1 \\
1(0.56-1.79) \\
1.71(0.49-6.05) \\
1.71(0.87-3.38) \\
5.25(1.49-18.54)\end{array}$ & NSt \\
\hline $\begin{array}{l}\text { HRQoL } \\
\text { Parent relations } \\
\text { High } \\
\text { Middle } \\
\text { Low }\end{array}$ & $\begin{array}{l}18.5 \\
25.5 \\
30.9\end{array}$ & $\begin{array}{c}1 \\
1.97(1.01-3.84) \\
1.50(0.77-2.93)\end{array}$ & $\begin{array}{l}1.85(0.88-3.86) \\
2.68(1.22-5.85)\end{array}$ \\
\hline $\begin{array}{l}\text { Peers and social support } \\
\text { High } \\
\text { Middle } \\
\text { Low }\end{array}$ & $\begin{array}{l}31.2 \\
22.6 \\
33.3\end{array}$ & $\begin{array}{c}1 \\
0.65(0.39-1.06) \\
1.10(0.58-2.11)\end{array}$ & $\begin{array}{c}1 \\
0.46(0.26-0.82) \\
0.63(0.29-1.38)\end{array}$ \\
\hline $\begin{array}{l}\text { School environment } \\
\text { High } \\
\text { Middle } \\
\text { Low }\end{array}$ & $\begin{array}{l}20.0 \\
19.2 \\
36.2\end{array}$ & $\begin{array}{c}1 \\
0.95(0.44-2.06) \\
2.27(1.10-4.71)\end{array}$ & NS \\
\hline
\end{tabular}

HRQoL: health-related quality of life.

${ }^{*}$ Crude odds ratios obtained through bivariate logistic regression.

** Adjusted odds ratios obtained through multivariate logistic regression, including all variables described in the table.

+ Variables excluded from the multivariate model once their lack of significance was verified. NS: not significant.

TABLE 4. Factors associated with unsatisfactory annual average academic performance by socioeconomic level

\begin{tabular}{|c|c|c|c|c|c|c|}
\hline & \multicolumn{3}{|c|}{ Middle-low SEL $(n=242)$} & \multicolumn{3}{|c|}{ High SEL $(n=108)$} \\
\hline & $\%$ & ${ }_{c} \mathrm{OR}(95 \% \mathrm{CI})^{*}$ & OR $(95 \% \mathrm{CI})^{* *}$ & $\%$ & ${ }_{c} \mathrm{OR}(95 \% \mathrm{CI})^{*}$ & ${ }_{\mathrm{a}} \mathrm{OR}(95 \% \mathrm{CI})^{* *}$ \\
\hline \multicolumn{7}{|l|}{ School age } \\
\hline Theoretical age & $20.6^{+}$ & 1 & & $19.3^{+}$ & & \\
\hline $\begin{array}{l}1 \text { year older than expected } \\
2 \text { or more years older }\end{array}$ & 37.1 & $2.27(1.20-4.30)$ & $2.03(1.00-4.09)$ & 53.3 & $4.77(1.52-14.99)$ & $7.52(2.01-28.13)$ \\
\hline than expected & 31.4 & $1.77(0.79-3.96)$ & $1.34(0.55-3.27)$ & 66.7 & $8.35(2.25-31.01)$ & $10.60(2.10-53.51)$ \\
\hline \multicolumn{7}{|l|}{ HRQoL } \\
\hline \multicolumn{7}{|l|}{ Autonomy } \\
\hline High & 37.8 & 1 & & 37.5 & & \\
\hline Middle & 21.5 & $0.53(0.27-1.03)$ & $0.46(0.22-0.98)$ & 32.1 & 3.27 (1.09-9.79) & 3.89 (1.03-14.63) \\
\hline Low & 28.0 & $0.45(0.21-0.96)$ & $0.35(0.15-0.80)$ & 16.0 & $3.99(1.13-14.08)$ & $4.17(0.95-18.31)$ \\
\hline \multicolumn{7}{|l|}{ School environment } \\
\hline High & 5.3 & 1 & & $46.4^{+}$ & & \\
\hline Middle & 22.9 & $1.26(0.46-3.41)$ & $1.07(0.37-3.11)$ & 20.8 & $0.69(0.18-2.69)$ & $0.81(0.15-4.41)$ \\
\hline Low & $41.9^{+}$ & $2.99(1.16-7.73)$ & $3.13(1.11-8.82)$ & 20.0 & $1.64(0.46-5.82)$ & $1.71(0.34-8.51)$ \\
\hline
\end{tabular}

SEL: socioeconomic level; HRQoL: health-related quality of life.

* Crude odds ratios obtained through bivariate logistic regression. ** Adjusted odds ratios obtained through multivariate logistic regression, including all variables described in the table. + Statistically significant differences $\left(\chi^{2} p<0.05\right)$ in the distribution of academic performance for each variable, within the middle-low SEL group or the high SEL group. 
may have better emotional and social abilities, which in turn favor a satisfactory academic performance. ${ }^{26}$ In terms of perceived health, adolescents with low grades showed a worse perception regarding parent relations and school environment. The effect of school environment was higher among low SEL participants.

Although the sample size was sufficient to verify that most differences were statistically significant, the high number of students who did not participate due to their parents refusal to sign the informed consent may present a risk of bias should academic performance and HRQoL be associated with the reasons for not participating.

Another limitation of this study is that, given its cross-sectional design, it was not possible to establish causative relations between the studied events. Future longitudinal investigations may account for the effect of health and sociodemographic variables on AP among adolescents. One hypothesis to be proposed may be that adequate health is necessary for optimal learning and academic performance, but a two-way relationship is also suggested here. ${ }^{11,12}$ Although, to date, there is scarce evidence regarding the impact of academic performance on health perceived byyouth, some studies ${ }^{27,28}$ suggest that adolescents who report better grades also tend to report a better perceived health; therefore, a longitudinal study of these variables would allow to establish the type of relationship and dynamics between them.

Among the strengths of this study, it is worth pointing out that two relevant aspects of adolescent life such as education and health were herein analyzed, the latter from its own perspective. Based on this pilot study, it would be interesting to recommend additional development of such pediatric research approaches to understand other aspects of adolescent health.

\section{CONCLUSION}

This study shows the relationship between academic performance and self-perceived health among adolescents, and suggests that psychosocial dimensions of HRQoL, such as family and peer relations, autonomy and school environment, are essential to analyze low academic performance in this age, which is also influenced by school age, sex and SEL.

\section{Acknowledgments}

We would like to thank the authorities, teachers and students from the participating schools. Also, to the research team of Center for Epidemiological Research and Health Services, and especially Verónica Mamondi, MSc, for her help coordinating and conducting the field work. And to María Eugenia Esandi and Mariana Roizen, who read the draft version of the manuscript and provided major comments to improve its content.

\section{REFERENCES}

1. National Research Council and Institute of Medicine. Committee on Evaluation of Children's Health Board on Children, Youth and Families, Division of Behavioral and Social Sciences and Education. Children's Health, the Nation's Wealth: Assessing and Improving Child Health. Washington, DC: National Academies Press; 2004.

2. Starfield B. Basic concepts in population health and health care. J Epidemiol Community Health 2001;55(7):452-4.

3. Starfield B. Measurement of outcome: a proposed scheme. Milbank Mem Fund Q Health Soc 1974;52(1):39-50.

4. Rajmil L, Díez E, Peiró R. Desigualdades sociales en la salud infantil. Informe SESPAS 2010. Gac Sanit 2010;24(1):42-8.

5. Melchior M, Moffit TE, Milne BJ, Poulton R, Caspi A. Why dochildren from socioeconomically disadvantaged families suffer from poor health when they reach adulthood? A lifecousestudy. Am J Epidemiol 2007;166(8):966-74.

6. Edel Navarro R. El rendimiento académico: concepto, investigación y desarrollo. REICE 2003;1(2):1-15.

7. Martínez Carpio H. Autopercepción social y atribuciones cognoscitivas en estudiantes de bajo rendimiento académico. Rev Electrón Investig Psicoeduc Psigopedag 2009;7(3):1175-1216.

8. Acero Abdul G, Talman Peluha A, Vergara Galván A, Moreno Méndez J, Jiménez Martín H. Relación entrehábitos de salud, consumo de internet y rendimiento académico en adolescentes de un colegio de la ciudad de Bogotá. Psicogente 2008;11(19):9-23.

9. Solans M, Pane S, Estrada M, Serra-Suton V, et al. Healthrelated quality of life measurement in children and adolescents: A systematic review of generic and diseasespecific instruments. Value Health 2008;11(4):742-64.

10. Rajmil L, Roizen M, Psy AU, Hidalgo-Rasmussen C, et al. Health-related quality of life measurement in children and adolescents in Ibero-American countries, 2000 to 2010. Value Health 2012;15(2):312-22.

11. Forrest CB, Bevans KB, Riley AW, Crespo R, Louis, TA. Health and school outcomes during children's transition into adolescence. J Adolesc Health 2013;52(2):186-94.

12. Ickovics JR, Carroll-Scott A, Peters SM, Schwartz M, et al. Health and academic performance: cumulative effects of health assets on standardized test scores among urban youth in the United States. J Sch Health 2014;84(1):40-8.

13. Ojembarrena Martínez E, Fernández de Pinedo Montoya R, Gorostiza Garay E, Lafuente Mesanza P, Lizarraga Azparren MA. Fracaso escolar en adolescentes y factores sociosanitarios asociados. An Esp Pediatr 2002;56(5):416424.

14. KIDSCREEN Group Europe. The KIDSCREEN Questionnaires.Quality of LifeQuestionnaires for Children and Adolescents Handbook. Lengerich: Papst; 2006.

15. Detmar S, Bruil J, Ravens-Sieberer U, Gosch A, Bisegger $\mathrm{C}$; The European KIDSCREEN group. The Use of Focus Groups in the Development of the KIDSCREEN HRQL Questionnaire. Qual of Life Res 2006;15(8):1345-53.

16. Ravens-Sieberer U, Gosch A, Rajmil L, Erhart M, et al. The KIDSCREEN-52 quality of life measure for children 
and adolescents: psychometric results from a crosscultural survey in 13 European countries. Value Health 2008;11(4):645-58.

17. Berra S, Bustingorryf V, Henze C, Díaz MP, et al. Adaptación transcultural del cuestionario KIDSCREEN para medir la calidad devidarelacionada conlasaluden poblaciónargentina de 8 a 18 años. Arch Argent Pediatr 2009;107(4):307-14.

18. BerraS, TebéC,EsandiM,Carignano C. Fiabilidad y validez del cuestionario KIDSCREEN-52 para medir calidad de vida relacionada con la salud para población argentina de 8 a 18 años. Arch Argent Pediatr 2013;111(1):29-36.

19. Currie C,Molcho M, Boyce W, Holstein B, etal. Researching health inequalities in adolescents: the development of the Health Behaviour in School-Aged Children (HBSC) family affluence scale. Soc Sci Med 2008;66(6):1429-36.

20. Suldo SM, Riley KN, Shaffer E J. Academic Correlates of Children and Adolescents' Life Satisfaction. Sch Psychol Int 2006;27(5):567-82.

21. Palacio-Vieira JA, Villalonga-Olives E, Valderas JM, Espallargues M, et al. Changes in health-related quality of life (HRQoL) in a population-based sample of children and adolescents after 3 years of follow-up. Qual Life Res 2008;17(10):1207-15.

22. Villalonga-Olives E, ForeroCG, ErhartM,Palacio-VieiraJA, et al. Relationship between life events and psychosomatic complaints during adolescence/youth: a structural equation model approach. J Adolesc Health 2011;49(2):199205.

23. Santrock J. Psicología de la educación. México: McGraw Hill Interamericana; 2002.

24. Martínez Carpio H. Autopercepción social y atribuciones cognoscitivas en estudiantes de bajo rendimiento académico. Rev Electrón Investig Psicoeduc Psigopedag 2009;7(3):1175-216.

25. Casassus J, Cusato S, Froemel JE, Palafox JC, et al. Primer estudio internacional comparativo sobre lenguaje, matemáticas y factores asociados, para alumnos de tercer y cuarto grado de la educación básica. Informe técnico. Santiago: Laboratorio Latinoamericano de Evaluación de la Calidad de la Educación, UNESCO; 2001.

26. Jadue JG. Transformaciones familiares en Chile: Riesgo creciente para el desarrollo emocional, psicosocial y la educación de los hijos. Estud Pedagóg 2003;29:115-26.

27. Karvonen S, Vikat A, Rimpela M. The role of school context in the increase in young people's health complaints in Finland. J Adolesc 2005;28(1):1-16.

28. Piko BF. Self-perceived health among adolescents: the role of gender and psychosocial factors. Eur J Pediatr 2007;166(7):701-8. 